\title{
Digital technologies and development of clusters in the light industry of the PRC
}

\author{
Yuan Zheng ${ }^{1 *}$ \\ ${ }^{1}$ Saint Petersburg State University of Industrial Technologies and Design, 191186 Bolshaya \\ Morskaya st. 18, Russian Federation
}

\begin{abstract}
China has demonstrated during the last thirty years the highest and the most stable GDP growth rate. It has helped the country become the biggest world exporter and significantly increase the social standard of living. However, the growth potential within the boundaries of engineering capability existing before has its limits and during the next $10-15$ years the country will not be able to demonstrate the two-digit growth rate again. The same as the other industrially developed countries China has outlined the national prospects in the sphere of wide use of digital technologies. In this respect the development of textile sector of economics with more than $11 \mathrm{mln}$. people engaged is of a considerable interest. The article gives analysis to the new trends in industry development and offers new organizational models. It has been shown that in case of implementation of innovative development scenario and wide use of digital technologies the average annual growth rates in the period of 2018-2025 will be by $0.8-1.0$ percentage points higher than in 2015-2016.
\end{abstract}

\section{Introduction}

China has gone through three stages of development in the light industry sector by this time [1]. The first stage is a prereform one (1949-1978), the second stage is a transitional one (1978-2000) and the third stage is the stage of renovation (2000-2013). The high average annual growth rate of the industry of $14 \%$ has been characteristic for the second stage, which ensured the domination of China in the world market of textile by 2000 . At the same time it should be noted that the world market environment and internal conditions too have changed greatly by this time. First of all, a trend has emerged to the drop of sector's share in the volume of added tax and industry's export. If the value of the first indicator in 1990 equaled $14.8 \%$, in 2007 it equaled $9.9 \%$, as for the second indicator, its share decreased from $16.3 \%$ in 1997 to $9 \%$ in 2010 [1]. It took place against the background of root changes in the structure of ownership. By 2011 the share of state enterprises in the sector dropped down to $1.2 \%$ (124 enterprises), when the share of private enterprises grew up to $59.9 \%$ (6,060 enterprises) and enterprises based on the foreign capital and with their participation grew up to $36.9 \%$ (3,938 enterprises). Thus, the number of medium and big enterprises in the sector (with the number exceeding 270 pers.) amounted to 10,122 with $3.24 \mathrm{mln}$. people employed thereat. Totally there were already 18,547 enterprises by that time in the

\footnotetext{
*Corresponding author: yuanzheng.chaos@gmail.com
} 
sector including small and private households [1]. Two trends of macroeconomical nature have been characteristic for the third stage; they have taken the attractiveness and competitiveness of the sector down: the average annual growth rate of the salary amounted to $8.21 \%$ against the background of decreasing volumes of foreign investments into Chinese industry from $1.9 \mathrm{bln}$. dollars to $1.6 \mathrm{bln}$. dollars [1]. It has taken place against the background of a considerable deceleration of economic growth: in 2013 and 2014 the results were the lowest during the last six years. At the same time the number of newly established working places in the period since January till March 2013 appeared to be lower by 200 thousand, than over the same period of 2012: 3.24 million against 3.44 million. The level of unemployment in China in 2013 was about $4.1 \%$. The maximum value of indicator was registered in 2012 and 2011 over the last ten years [2].

Since 2000 China had launched a wide expansion of financial investments to foreign countries and by 2011 the total volume of such investments had amounted to $430 \mathrm{bln}$. dollars. In particular, already by 2005 more than $780 \mathrm{mln}$. dollars have been invested into textile production of such countries as Cambodia, Bangladesh and Myanmar [3]. Thus, one can acknowledge that a necessity overdue by 2013 in the sector of light industry of China to identify new lines of development [4] as a result of:

- involvement of Chinese textile industry into a global chain of supplies and location of new production capacities outside of China;

- sharp reduction of the share of sector in the added value and export of industry;

- cycle between production and end user extended in time (it makes ten weeks instead of two weeks);

- beginning of wide structural reforms in Chinese industry with the launched transition from textile production to the production of goods of industrial application and durable goods, hi-tech produce and development of real estate sector.

In this respect the incorporation of innovations, for instance, based on digital technologies becomes especially relevant: automated systems of developing new models of clothes (CAD), automated systems of manufacture (CAM), systems of planning results at enterprise (ERP).

\section{Innovations and digital technologies}

A great number of small and family enterprises work in textile industry of China, which main focus is the survival, but not the technological innovation. The other problem is a low educational level of managers at the textile enterprises, which brings about the insufficient competencies, information about market and, as a result, weakening positions in the struggle for leadership. In parallel to that, most frequently no strategic plans are available, while the information systems are imperfect and poorly integrated with the other part of companies' activity.

An important direction in mastering new segments of the market is the concept of personalization of satisfying the mass-consumer's request being actively developed in the world, which contemplates a number of new innovative capabilities for the manufacturers of clothes. In order to use this capability, the customers should understand better what is possible from the point of view of product and clothes personalization under particular production facility capabilities.

A Program of development of digital community and economy of China initiated by the State Council of the PRC in 2007 in the form of system of data acquisition about clients of banks with the aim of determining paying capacity thereof in accordance with the available information, payment and credit record shall become one of the possible tools for implementing this concept [5]. Similar programs exist already in some countries, for instance, in the USA [6]. 
The designing of full-scale system Social Credit Score (SCS) began in China since 2014 , the beginning of experimental version of "credit social system" is planned for 2018 for several cities in China. This system envisages that the ratings will be awarded not only to physical persons but to legal entities too. Thus, the companies will be motivated to provide reports in time, pass all the checks and inspections in good faith in exchange for the privileged business conditions.

The government has adopted a decision to build SCS system with 10 companies, including giants Alibaba and Tencent. Two biggest Internet companies have launched identical applications for gadgets, which after receiving authorization from the registered user; have received all the available information about him. Tencent Company mainly uses the messenger programs for transmitting brief messages. They managed to collect more than a billion of users [7]; the Internet giant Alibaba acquires information via proprietary application Alipay about effected payments of the users, paid purchases, etc. More than half-million of the users [8] are involved in it. Additionally, both applications get information about actions of an individual from municipal authorities, police departments, research centers and private companies. The user's rating is built on its basis: the higher is the rating, more bonuses receives an individual.

High, stable and long-standing high rate of Chinese economics growth have contributed to the emergence of nodal points; the following are to be specifically singled out among them:

- deficit of qualified workers, technicians and engineers in line with high unemployment of wide public lacking required competences and skills;

- necessity of advanced development of machine-building, which produce shall provide for furnishing new and upgrading existing light industry enterprises;

- vertical integration of light industry enterprises and bunching thereof with the aim of increasing the scale of production, increasing level of yield and proceeds, build-up and increase of efficiency of economic activity, reduction of tax burden.

In order to solve these nodal problems in the sector of light industry of China, it is absolutely essential to shape a national innovative system, including such components as R\&D purpose-oriented programs for the development of inherent patents and process renovation and wide use of the up-to-date digital technologies: automated systems of developing new models of clothes (CAD), automated systems of manufacture (CAM), systems of planning results at enterprise (ERP), data transfer technologies (EDI, RFID and bar-codes), information platforms on markets, products, consumers and contents (MAP, PIM, CRM, CMC).

\section{New configuration of clusters}

The further development of light industry of China is associated with the establishment of clusters maximizing its presence in the global chain of produce added value. The basic principles of building clusters have been suggested in due time by M. Porter $[9,10]$.

The investigators point out: “...the cluster policy has acquired an ever more significance in the sewing and textile production during the last decade" [11]. The clusters contribute to:

- steady and efficient networking between enterprises of different industries;

- information exchange aimed at improving technical and economical characteristics and consumer properties of manufactured produce, used technology and equipment;

- coordination of investment and innovative activity;

- reduction of expenses, increasing volume of output and competitiveness.

The "supplier-consumer"-type relations are used as a basis of one of the developed forms of building clusters. For instance, the textile industry of Shaoxing consists of the 
production chain formed by such sectors as the production of chemical fibers, weaving industry, printing and fabrics dyeing [12].

Apart from the factories focusing activity on the main business processes from the chain of added value of product line, the industrial cluster shall include enterprises and organizations providing its activity. The following is to be attributed to such enterprises and organizations with respect to light industry:

- universities, professional educational institutions and other educational establishments training personnel;

- machine-building enterprises specializing in manufacturing products for the cluster enterprises;

- centers conducting scientific, experimental-and-design and engineering activity in the cluster's interests as well as coordinating the marketing, innovative, investment and product policy determining specialization capabilities thereof;

- bank organizations, which provide financing;

- wholesale and retail organizations engaged in produce selling.

The detailed information about composition of the light industry clusters in Jiangsu and Zhejiang provinces is comprised in [13].

The conducted analysis makes it possible to offer a number of additions to the light industry clusters of China, which can be considered by the example of clothes production. The suggested cluster as compared with the existing ones shall feature an extended composition.

It is offered to include not only educational institutions into composition of the extended cluster as it is implemented, for instance, in the Russian legislation [14], but the banking institutions as well as machine-building enterprises specializing in manufacturing equipment for the cluster. The suggested cluster composition makes it possible to implement in principle the entire chain of clothes production added value, since:

- cluster core is formed by the enterprises of several light industry branches, which are to be integrated. The integration implies synchronization of produce output volumes and coordination of price policy with the aim of minimizing expenses and taxation burden with restricting prices for final produce.

- interests of owners of enterprises producing raw materials and intermediate produce can be satisfied by means of receiving a share of ownership in the sewing industry and trading enterprises featuring high profitability.

Thus, it is proposed to attribute the following to the necessary participants of the lightindustry cluster providing its functioning and development:

- bank providing budgeting of current activity of all enterprises and organizations as well as implementation of innovative and investment policy;

- universities and secondary technical educational institutions, which basic function is to train personnel. The universities play a central role, since they train personnel for all enterprises, including inherent needs. Besides, a part of, and maybe all scientific investigations and experimental-and-design developments shall be concentrated also there;

- fashion houses fulfill a function of renovation and forming product line, develop and catch up fashionable trends, perform promotion of cluster's produce due to use of its brands;

- engineering center is engaged in the development of new products, technologies, equipment, fulfillment of scientific investigations in technical and economic field, forms and effects implementation of innovative and investment policy;

- machine-building participates directly in implementation of investment policy. The equipment is to be manufactured within time limits recorded in the cluster's investment program for every enterprise participating in implementation of this program. 


\section{Model and results of its verification}

The innovations, digital technologies and new models of business organization for the light industry of China set more complete saturation of the market with goods, provision of personal requests of the customers and, as a result, growth of volumes of the manufactured produce as the final goal.

In order to assess the industry's potential; we have offered one of modifications of Cobb-Douglas production model widely used in economical literature in the following form:

$$
\tilde{Y}=\gamma \cdot K^{\alpha} \cdot[A \cdot L]^{1-\alpha+\varepsilon}
$$

where:

$\tilde{Y}$ - design volume of added value of the light industry of the PRC in comparable prices of 2010.

$\mathrm{K}$ - capital assets in the light industry of the PRC in comparable prices of 2010.

A - change of multifactor productivity in the PRC.

$\mathrm{L}$ - number of employees in the light industry of the PRC.

$\gamma, \alpha, \varepsilon-$ model parameters.

In order to provide for higher accuracy of calculating according to the model, we have processed the dynamic rows of actual values for such indicators as the cost of fixed assets (capital), quantity of employed people and multifactor productivity on the basis of four data sources - National Statistical Office of PRC [15], University of Groningen (the Netherlands) [16], Organization for Economic Cooperation and Development (OECD) [17], and World Bank [18]. In view of specific features of running a system of national accounts in the PRC, it is not always possible to provide for correct data comparability, therefore, it is necessary to address the other sources providing more accurate data, especially in terms of industrial product prices, multifactor productivity (to be calculated for the whole economics) and inflation rate. Therefore, in order to carry out calculations, the cost of fixed assets was recalculated in prices of 2010, while the multifactor productivity was corrected to 1998 , the baseline one for making calculations. The volume of added value of the light industry has been determined as the sum of volumes of three sub-industries: production of fabrics, threads and fibers (textile); sewing industry; leather and footwear industry, fur industry and headgear production.

The calculation results according to the suggested model are shown in Table 2, at that, the values of basic parameters were as follows: $\gamma=0.101 ; \alpha=1.174 ; \varepsilon=0.796$.

Table 2. Results of forecast calculations for light industry of PRC.

\begin{tabular}{|c|c|c|c|c|c|}
\hline \multirow{2}{*}{ Year } & $\begin{array}{c}\text { Capital in prices of } \\
2010\end{array}$ & $\begin{array}{c}\text { Q-ty of } \\
\text { employed }\end{array}$ & Multifactor productivity & \multicolumn{2}{|c|}{$\begin{array}{c}\text { Added value in prices of } \\
2010\end{array}$} \\
\cline { 2 - 6 } & bln. yuan & mln. people & $1998=1$ & bln. yuan & $\begin{array}{c}\text { growth rate, } \\
\%\end{array}$ \\
\cline { 2 - 6 } & $\tilde{K}$ & $\widetilde{L}$ & $\widetilde{A}$ & $\tilde{Y}$ & $\tilde{T}_{Y}$ \\
\hline 2017 & 152.8 & 11.7 & 1.609 & 230.8 & 9.0 \\
\hline 2018 & 161.0 & 11.6 & 1.625 & 245.4 & 6.3 \\
\hline 2019 & 169.2 & 11.5 & 1.639 & 260.0 & 6.0 \\
\hline 2020 & 177.2 & 11.4 & 1.651 & 274.5 & 5.6 \\
\hline 2021 & 185.1 & 11.3 & 1.661 & 288.8 & 5.2 \\
\hline
\end{tabular}




\begin{tabular}{|c|c|c|c|c|c|}
\hline \multirow{2}{*}{ Year } & $\begin{array}{c}\text { Capital in prices of } \\
2010\end{array}$ & $\begin{array}{c}\text { Q-ty of } \\
\text { employed }\end{array}$ & Multifactor productivity & \multicolumn{2}{|c|}{$\begin{array}{c}\text { Added value in prices of } \\
2010\end{array}$} \\
\cline { 2 - 6 } & bln. yuan & mln. people & $1998=1$ & bln. yuan & $\begin{array}{c}\text { growth rate, } \\
\%\end{array}$ \\
\cline { 2 - 6 } & $\tilde{K}$ & $\tilde{L}$ & $\tilde{A}$ & $\tilde{Y}$ & $\widetilde{T}_{Y}$ \\
\hline 2022 & 192.7 & 11.3 & 1.669 & 302.8 & 4.8 \\
\hline 2023 & 200.2 & 11.2 & 1.675 & 316.3 & 4.5 \\
\hline 2024 & 207.3 & 11.2 & 1.679 & 329.3 & 4.1 \\
\hline 2025 & 214.1 & 11.2 & 1.681 & 341.6 & 3.8 \\
\hline
\end{tabular}

According to our calculations the average-annual growth rate of light industry of PRC in the forecast zone will amount to 5.5\%, which exceeds the industry's indicators in 20152016 (4.7 and 4.2 percent, accordingly), but is significantly lower than the average-annual growth rate for the entire retrospective period (12.4\%). According to our opinion the provision of such high growth rate is impossible under the present-day economical conditions, since the measurement reference proper has changed, and the consumer itself has become more demanding to quality and range of produce of the sector. At the same time it should be noted that the industry growth rates obtained on the basis of the model exceed significantly the growth rate of gross domestic product (GDP) of China for the same period, which have been calculated by a number of reputable research centers: two reputable research centers - RAND Corporation [19] and the Conference Board [20] have published the forecasts of annual-average growth rate of China's GDP for a period of 20162025 within an interval of four years (2011 and 2015). It is notable that in the first forecast such growth rates are evaluated in the interval from 3.8 to 9.0 percent (average of 5.7), in the second forecast these rates are considerably lower: 4.5 percent for a period of 20162020 and 3.6 percent for a period of 2021-2025.

Since the annual-average growth rate of the volume of industry's added value in the forecasting period amounted to 5.5 percent, we will interpret the difference in rate characteristics between the forecast and actual indicators for 2015-2016 (4.7 and 4.2 percent) as an effect, which can be obtained by the industry as a result of cluster-type organization model and new tools of implementing the innovative policy in the industry. The graphical trajectory of industry development itself for a period until 2025 is shown in Fig. 1. 


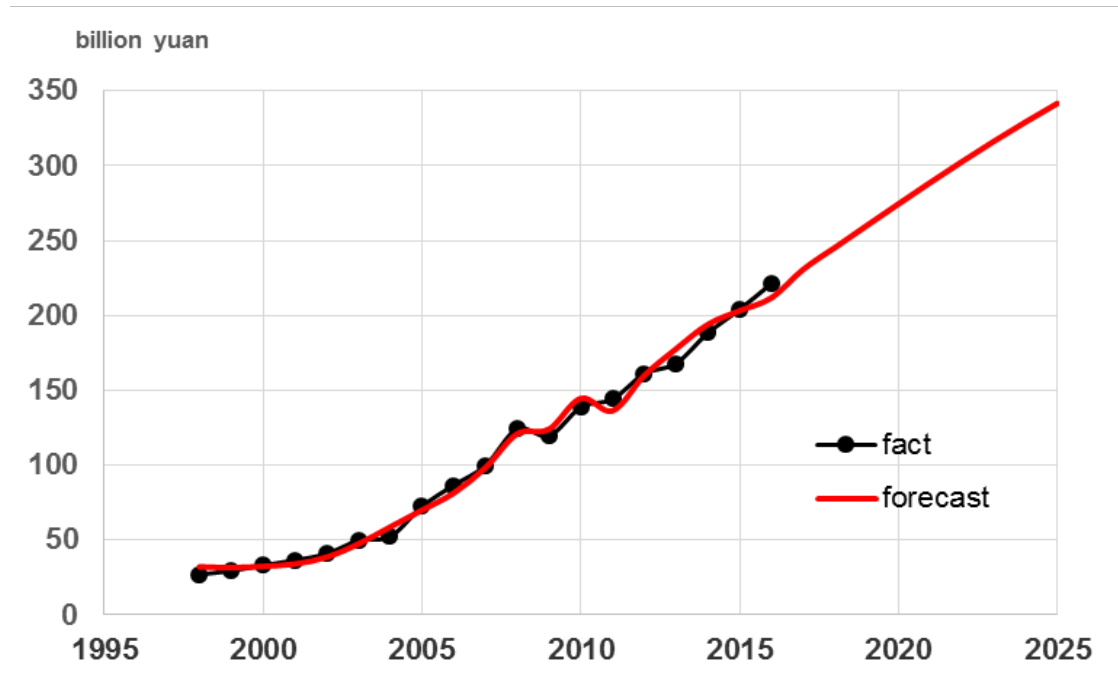

Fig. 1. Forecast of added value of china's textile industry.

The graph shows that the model suggested by ourselves gives quite an accurate description of dynamics of the industry's dynamic growth, while the model's error does not exceed $0.6 \%$. Such a high accuracy of calculation has been provided due to correct selection of models describing dynamics of the model's basic factors - capital, quantity and multifactor productivity.

\section{Conclusion}

The development of textile sector of China on a new technological basis can play a role of stabilization factor for the national economy for two reasons. The first one consists in that the internal market will be provided with the proper-quality goods by the affordable prices. The second reason consists in that the sector can become a reliable source of export proceeds due to a wide use of new digital technologies. In combination these two factors can make a basis for the new qualitative growth of the country's textile industry in the nearest $10-15$ years.

\section{References}

1. M. Zhang, ERIA Discussion Paper Series, 12 (2015)

2. E. Bazhenova, A. Ostrovsky, Otechestvennyye Zapiski, 3 (2008)

3. S. Wang, H. Liu, F. Qian, J. Chen, X. Zhang (eds.), Report on Development of China's Outward Investment and Economic Cooperation (Ministry of Commerce of the People's Republic of China, Beijing, 2011)

4. Ch. Yuan, Problems of Modern Economics, 2 (62) (2017)

5. Digital Single Market - Digitizing European Industry [online], Available at: http://europa.eu/rapid/press-release_MEMO-16-1409_en.htm (2016)

6. FICO At a Glance [online], Available at: http://www.fico.com/en/about-us\#at_glance (2018)

7. Tencent Announces 2017 Third Quarter Results [online], Available at: https://www.tencent.com/en-us/articles/15000651510741924.pdf (2017) 
8. Official website of Alipay [online], Available at: https://intl.alipay.com/ (2018)

9. M. Porter, On Competition (Harvard Business Press Books, Boston, 2008)

10. Yu. I. Efimychev, I. V. Zakharov, Bulletin of Nizhni-Novgorod Lobachevsky University, 1 (2005)

11. O. Korkmaz, T. D. Medeni, International Journal of Business and Government Studies. 4 (1) (2012)

12. Distinctive Features of Industrial Clusters of China [online], Available at: http://sapsan-logistics.ru/otlichitelnye-osobennosti-proizvods (2018)

13. List of Clusters by Specialization [online], Available at: http://sapsanlogistics.ru/spisok-klasterov-po-specializacii (2018)

14. On Industrial Clusters and Specialized Organizations of Industrial Clusters. Resolution of Government of RF No. 779 [online], Available at: http://gov.garant.ru/document?id=71050302\&byPara=1 (2015)

15. National Bureau of statistics of China [online], Available at: http://data.stats.gov.cn/english/easyquery.htm? cn=C01 (2018)

16. Groningen Growth and Development Centre [online], Available at: http://www.rug.nl/research/ggdc/data/pwt/pwt-9.0 (2018)

17. Key Short-Term Economic Indicators [online], Available at: http://stats.oecd.org/index.aspx?DatasetCode=KEI\# (2018)

18. United Nations Industrial Development Organization [online], Available at: http://data.un.org/Data.aspx?q=value+added\&d=UNIDO\&f=tableCode\%3a20 (2018)

19. Jr. Wolf Ch., J Dalal S., J. Da Vanzo, V. Eric, E. V. Larson, A. Akhmedjonov, H. Dogo, M. Huang, S. Montoya, China and India, 2025 A Comparative Assessment [online], Available at: https://www.rand.org/content/dam/rand/pubs/monographs/2011/RAND_MG1009.pdf (2011)

20. A. A. Erumban, K. de Vries, Global Growth Projections for The Conference Board Global Economic Outlook 2016 [online], Available at: https://www.conferenceboard.org/attach/GEO_Methodology_Oct20151.pdf (The Conference Board. NY. 2015) 